\title{
The Relationship between Employees' Empowerment and Innovative Work Behavior
}

\author{
Dr.Dina Alkhodary \\ Assistant Professor \\ Al-Isra University
}

\begin{abstract}
This study focus on the employees empowerment and its relationship with the innovative work behavior as the modern organization looking for creativity and new ways of doing business, as well as most of managers nowadays aware of the importance of the employees training, development and empowerment. This research aimed to find out the relationship between employees empowerment and the creativity in doing their tasks, jobs and business. The generation of the study is the interior design companies in Jordan and the sample of study is the marketing, Human resources, customer service, Sales and Design departments as those departments must met the high standards of innovation and creativity in order to sell its products competitively. The researcher has used the questioner to collect data for the research purpose. "SPSS" statistical package program has been used to analyze the collected data through the questionnaire. The following statistical methods have been used: Frequencies and percentages, Means and standard deviations, Multiple Regression test. The study shows that there is a significant relationship between employee empowerment (Meaning, Competency, self determination, Impact) and innovative work behavior (Originality, Fluency of ideas, Problem sensitivity).
\end{abstract}

Keywords: employee empowerment, innovative, training, development, business.

\section{INTRODUCTION}

To cope with increased competitive pressure globalization and demand for efficiency, many organizations have come to rely on the strategy of employee empowerment as a tool to motivate its employee to be more productive as well as to be more loyal to the company and being more innovative in doing their tasks. This study intended to study the relationship between employee empowerment and innovative work behavior, by reviewing the literature about the definitions of both terms (employee empowerment, innovative) the researchers found that the empowerment has defined as a process of enhancing feelings of self-efficacy among organizational members through the identification of conditions that foster powerlessness, and through their removal by both formal organizational practices and informal techniques of proving efficacy information, Conger and Kanungo (1988). According to Conger and Kanungo, the effect of empowerment is the initiation and persistence of behavior by empowered employees to accomplish task objectives. Thomas and Velthouse (1990), however, argued that the concept of empowerment is much more complex and could not be fully explained in a one dimensional construct such as self-efficacy. They therefore define empowerment as an intrinsic task motivation that manifests itself in four cognitions (meaningfulness, competence, impact and choice or self-determination), reflecting an individual's orientation to his or her work roles.

Bowen and Lawler (1992) define employee empowerment as sharing with front-line employees, information about an organization's performance, information about rewards based on the organization's performance, knowledge that enables employees to understand and contribute to organizational performance, and giving employees the power to make decisions that influence organizational direction and performance. According to Zemke and Schaaf (1989), employee empowerment means turning the front-line loose, and encouraging and rewarding employees to exercise initiative and imagination.

Innovative work behavior encompasses all employee behavior related to different phases of the innovation process it focuses on something new, for the relevant unit of adoption. Employees who take the initiative to copy successful work habits from other departments, (Kanter, 1988). 
Innovative work behavior makes an explicit reference to the distinct parts of the innovation process. A problem is recognized, a idea for a solution is generated and developed, the idea is proposed, defended and eventually implemented in the organization (Kanter, 1988).

Knowing that a normal innovation process is iterative, time consuming and complex (Kanter, 1988; Scott \& Bruce, 1994; Tuominen \& Toivonen, 2011), researchers distinguish between particular employee behavior related to the different phases of the innovation process. As such, some authors refer to two dimensions: idea generation and idea implementation (De Jong \& Den Hartog, 2007; Yuan \& Woodman, 2010), while other suggest three dimensions: idea generation, idea championing and idea implementation (Carmeli, Meitar, \& Weisberg, 2006; Janssen, 2000; Messmann \& Mulder, 2011; Reuvers, van Engen, Vinkenburg, \& Wilson-Evered, 2008; Scott \& Bruce, 1994). Some others refer to four (e.g. de Jong \& Den Hartog, 2010) or even five dimensions (e.g. Kleysen \& Street, 2001). Nevertheless, only rarely these dimensions can actually be distinguished in the empirical data and separate analyses are performed for the separate dimensions.

\section{LITERATURE REVIEW}

\subsection{Employee Empowerment}

Saeed (2013) this study attempts to check the impact of empowering employees on job satisfaction among middle level managers of JVC Descon, Lahore, Pakistan. The aim is to measure level of employee empowerment, level of job satisfaction and to test the relationship between employee empowerment and job satisfaction. To check the reliability and validity of the questionnaire as a research instrument, statistical tests were performed. The questionnaires were distributed to them and later filled ones received back through email. Sixty questionnaires were distributed and 52 questionnaires, with $86.6 \%$ response rate, were received back. The results of this study show that middle level managers of JVC Descon are more satisfied with their job as a result of granting them more empowerment to them.

Baek (2010) this paper examines the influence of psychological empowerment on organizational commitment and the moderating effect of organizational learning culture on the relationship. The results suggest that psychological empowerment, organizational learning culture, and demographic variables had a significant impact on organizational commitment for employees in the public sector of Korea. Employees showed higher organizational commitment when they perceived high psychological empowerment and a high organizational learning culture. In addition, the moderating effect of organizational learning culture on the relationship between psychological empowerment and organizational commitment was found to be significant. Among the demographic variables, only educational level turned out to be significant.

Jyostsna (2007) Employee commitment continues to be one of the most exciting issues for both practitioners and academicians. Linkages in literature are found for HRM Practices, but there is a lacuna of research linking organizational commitment and strategic HR roles, psychological empowerment as well as organizational learning capability. This study examines these linkages. Whether these variables predict organizational commitment in Indian managers or not, is also investigated. The sample size of the study comprises of 640 Indian managers.

Melinda (2006) in this study the Results, bounded by sample and focal organizational characteristics, indicated that employees who feel empowered in their work environment tend to have higher levels of interpersonal-level trust in their managers. An online survey designed to assess empowerment and trust was administered to a random sample of 2,000 salaried employees at a Fortune 500 manufacturing organization in the USA. The study has Highlights how increments in empowerment and trust can mitigate effects of organizational complexity, reduce transaction costs, strengthen relational systems within flatter organizational structures, and diminish the need for supervisory oversight, unproductive controls, and measurement systems that negatively impact productivity and the capacity to succeed in highly competitive markets.

Janssen (2004) the author proposes the idea that conflict with superiors has a barrier effect in the positive relationship between employee empowerment and organizational commitment. Superiors with higher authority rankings set and pursue organizational goals and values to which employees with lower authority rankings are expected to become committed. Conflicts with those superiors may hinder empowered employees to develop or maintain high levels of organizational commitment. A questionnaire survey among 91 secondary school teachers in The Netherlands provides empirical 
support for this suggestion. The moderator effect of conflict with superiors that was proposed and found in this study suggests that psychological empowerment in the workplace interacts with other employee experiences in its effects on an employee's commitment to the organization.

Hill (2004) the focus of this paper is a comparison of how managers and non-managers conceptualize employee empowerment, what they aim to achieve from it and what they actually achieve. Employee empowerment is a recent addition to the long line of involvement and participation initiatives that have been employed in Western economies. It is a management response to an increasingly complex and competitive external environment and its popularity has been enhanced by the quality movement in general.

\section{INNOVATIVENESS}

George (2006) the research embed the innovation production function in a model that analyzes the impact of innovation output on manufacturing multi-factor productivity (MFP) growth. The research combines a market share model with a gross output production function. This revenue approach enables a 'demand-shift' interpretation of the contribution of innovation to MFP growth. the research apply different sets of instrumental variables and different estimation methods to estimate simultaneously the returns from innovation investment to innovation output, the contribution of innovation output to productivity growth and the feedback link running from a firm's overall sales performance to its innovation endeavor. The results show that the estimation of return on innovation investment benefits from the inclusion of more information on the technological environment of the firm.

Hans (2006) the study examine sensitivity of the estimated relationship between innovation and firm performance. In doing so, the study rely on a knowledge production function approach and carry out comparisons in a number of ways. The sensitivity analysis is based on the comparison of a basic econometric model estimated assuming different error structure and using the same data source, an identical model but different data sources, different classifications of firms performance, different classifications of innovation and the two main different subpopulations of the business sector. The analyses are performed in both level and growth-rate dimensions. New findings are reported and previous results are confirmed as well. The study gives indications of what factors cause variations in the estimated effects of interest and the direction of changes.

Onne (2005) A questionnaire survey among 170 employees of a Dutch company showed that supervisor supportiveness moderated the relationship between employees' perceived influence in the workplace and their levels of innovative behavior. As hypothesized, the results suggest that when supervisors are perceived as being supportive of employee innovation, employees feel encouraged to use their influence to carry out innovative activities at work, whereas supervisors perceived as not being supportive inhibit them from doing so.

Onne (2004) the research aimed to explore factors and process mechanisms contributing to the benefits and costs individuals and groups incur from pursuing innovative approaches. With respect to individual innovation, such moderating factors might be found in the characteristics of the innovative idea, the innovator, coworkers, supervisors, the broader organizational context, and in national culture. Examples of factors that are likely to shape the beneficial and detrimental outcomes of group innovation include knowledge, skills and ability of group members, group tenure, diversity among group members, group processes (clarifying group objectives, participation, constructive management of competing perspectives), and external demands on groups. This Special Issue contains a state-ofthe-science paper, three articles dealing with the benefits and costs of individual innovation, and three articles addressing the bright and dark sides of group innovation.

James (2001) Research has found that employee suggestion systems are a useful way to obtain and utilize employees' creative ideas. To be effective, employees must be motivated to think creatively and to participate in the suggestion system. Unfortunately, motivating employees to participate is a common weakness of suggestion systems. Motivating employees involves more than simply offering rewards to submitters if their suggestions are put to use. According to expectancy theory, rewards will only motivate behavior if the rewards are valued, if they are closely linked to successful performance, and if employees believe that they can perform successfully. This paper applies expectancy theory to the problem of motivating employees to participate in a suggestion system. We describe suggestion system technology that will increase employees' motivation to think creatively and participate in the system. 
Luuk (2001) study has analyze the input and output stages of the innovation process and the links between the innovation process and overall economic performance. We investigate the existence of feedback links running from past economic performance to the input and the output stage of the innovation process and compare the results of a single-equation approach with the results obtained from a simultaneous-equation model.

\section{RESEARCH FRAMEWORK}

The research framework has been developed to find out the level of the employee empowerment in the insurance companies in Jordan and to identify the relationship between employees' empowerment and the innovative work behavior.

\section{Methodology}

A method has been designed to meet the objectives of the study, for this purpose a questioner has been adapted from three different studies Hasan Tutar (2011) and Shively (2011) and Se KIM, et al (2008).

The questioner has two parts, the first part is showing the demographic factors of the respondents, which include the position, gender, level of work experience and level of education, and the second part include 19 questions to measure if there is an employee's empowerment and work innovative behavior at the sample of the study and to find out if there is a positive relationship between them.

Sample of the study:

The sample of the study is the interior design companies in Jordan which are 8 companies and the sample of study is the marketing ,Human resources ,customer service, Sales and Design departments in the as those departments must met the high standards of innovation and creativity in order to sell its products competitively.

Source of data:

Primarily data was collected from 105 employees in the selected departments.

Secondarily data was collected from previous researches, article and internet.

Scope of the study- The study has covered 12 questions to measure the employee empowerment and 6 questions to measure the work innovative behavior

\section{HYPOTHESIS}

Three main hypotheses have been studied to find out if there is a positive relationship between employee empowerment and work innovative behavior.

\section{Hypothesis one is as follow:}

H0a: There is no significant relationship between the employee empowerment of the insurance companies in Jordan and innovative work behavior.

This hypothesis has four sub hypotheses as follow:

H0a1: There is no significant relationship between the (meaning) and innovative work behavior.

H0a2: There is no significant relationship between the (competency )and innovative work behavior.

H0a3: There is no significant relationship between the (self determination) and innovative work behavior.

H0a4: There is no significant relationship between the (impact) and innovative work behavior.

\section{Second hypothesis is as follow:}

H0b: There is no innovative work behavior at the companies in Jordan.

This hypothesis has three sub hypotheses as follow:

H0b1: There is no significant relationship between the employee empowerment and (Originality).

H0b2: There is no significant relationship between the employee empowerment and (Fluency of ideas).

H0b3: There is no significant relationship between the employee empowerment and (Problem sensitivity). 


\section{MOdel OF THE STUdY}

By reviewing previous studies and literature related to the topic of creativity, we could find that most of the researchers and authors are agree about these four main elements of empowerment and innovative work behavior.

Hasan Tutar (2011) has given a four stage empowerment model in which he has identified the following key employee job contents (Meaning, Competency, self determination, Impact)

- Meaning: the meaningfulness of the work for the employee depends on the meaningfulness of objective, responsibility and organizational purpose. Employee is expected to be satisfied as long as he or she considers the work as meaningful.

- Competency: For the employee to feel him or her competent the person should feel adept for the job and also, there should not be an inconsistency between his or her personality and the job.

- Self determination: Being self determinant means for one that he or she is able to define alternatives and choose between them. For the person to take initiative and to feel competent and responsible in his or her work is about self determination aspect.

- Impact: For an individual, to feel he or she is effective in his or her job means that he or she makes himself/herself believe that he/she has the ability to make a difference in his/her work environment.

And three variables to measure the innovative work behaviors which are (Originality, Fluency of ideas, Problem sensitivity)

- Originality: Originality is the quality that creates unique or extraordinary thoughts, unusual ideas, or the first of a kind Shively (2011).

- Fluency of ideas: The first step of creative endeavor or problem solving is having as many ideas as possible to choose from, research, or evaluate Shively (2011).

- Problem Sensitivity: is an ability to determine problems and being aware about the needs for change or for new approaches or methods Se KIM, et al (2008).
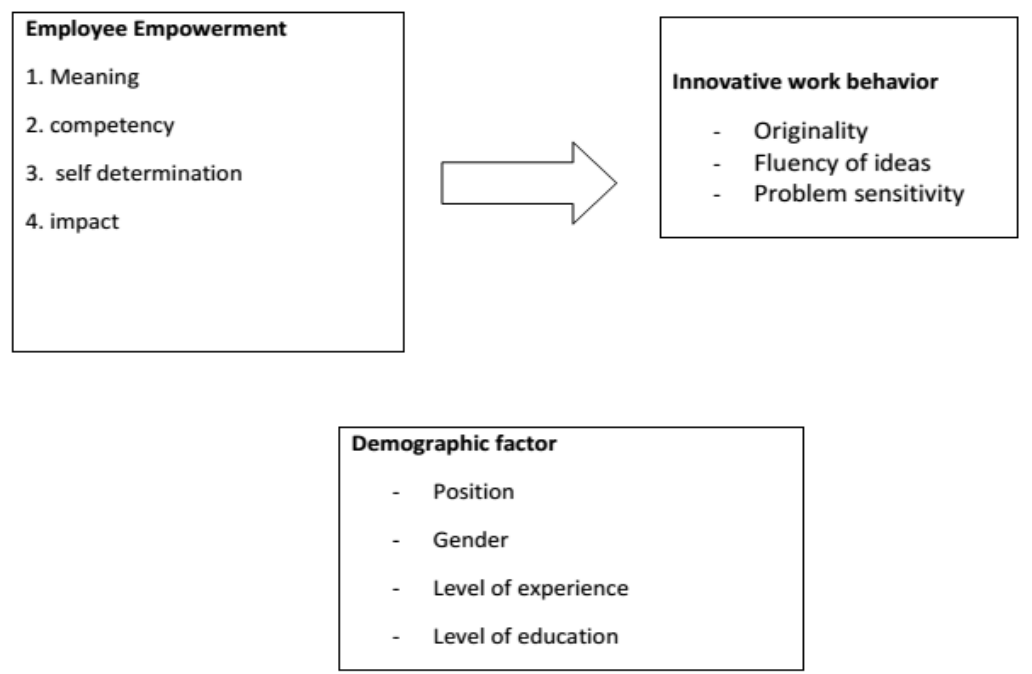

\subsection{Population and Sampling}

The population of the study has been interior design companies in Jordan, representing 8 corporations. The sample of study is the marketing, Human resources, customer service, Sales and Design departments in the as those departments must met the high standards of innovation and creativity in order to sell its products competitively. 105 questionnaires were retrieved, landing at 77.14 percent of the sample size.

\section{Reliability Test}

A Cronbach Alpha test has been used to ascertain instrument reliability. The value has been $=.865$ for the questionnaire. All values are accepted since they are more than 60\% (Malhotra, 2004). 


\section{QUESTIONNAIRE DESIGN}

The questionnaire has consisted of two main sections; the first has included participants' demographic (position, gender, level of experience, level of education), while the second section has included information that are regarding the recognizing of employee empowerment (1-12) and innovative work behavior (13-18).

5-points (Likert) scale has been used as follows: (5) points strongly agree, (4) points agree, (3) points neutral, (2) points disagree, (1) point strongly disagrees.

\section{Statistical Treatment Methods}

To analyze the collected data through the questionnaire, "SPSS" statistical package program has been used. The following statistical methods have been used:

- Frequencies and percentages

- Means and standard deviations

- Multiple Regression test

\section{ANALYSIS AND DiSCUSSION}

Frequency and percentages have been computed for the sample's characteristics.

Table1. Sample's Distribution According to Demographic Information

\begin{tabular}{|c|c|c|}
\hline & Frequency & Percent \\
\hline \multicolumn{3}{|c|}{ POSITION } \\
\hline Officer & 35 & 33.3 \\
\hline Senior & 42 & 40.0 \\
\hline Manager & 28 & 26.7 \\
\hline \multicolumn{3}{|c|}{ GENDER } \\
\hline Male & 63 & 60.0 \\
\hline Female & 42 & 40.0 \\
\hline \multicolumn{3}{|c|}{ Level of experience } \\
\hline Less than 3 years & 35 & 33.3 \\
\hline 3-5 Years & 35 & 33.3 \\
\hline More than 5 years & 35 & 33.3 \\
\hline \multicolumn{3}{|c|}{ Level of education } \\
\hline Diploma & 21 & 20.0 \\
\hline Bachelor & 70 & 66.7 \\
\hline Master & 14 & 13.3 \\
\hline
\end{tabular}

From the tables above, it is illustrated that $40 \%$ of the sample has at Senior Level, and $60 \%$ of the sample has been male, $33.3 \%$ of the sample has less than 3 years of experience, and 3-5 years of experience equally, and $66.7 \%$ of the sample has a bachelor degree

H0a: There is no significant relationship between the employee empowerment of the insurance companies in Jordan and innovative work behavior.

Multiple regressions is used to test this hypothesis, the results of regression the independent variables against innovative work behavior can be seen in table 5

Table 5, shows that $\mathrm{R}\left(.819^{\mathrm{a}}\right)$ is the correlation of the independent variables and innovative work behavior. Also it is found that R Square (.671), which is the explained variance.

Table5. Test of Ho

\begin{tabular}{|l|l|l|l|l|}
\hline Model & $\mathrm{R}$ & $\mathrm{R}$ Square & Adjusted R Square & Std. Error of the Estimate \\
\hline 1 & $.819^{\mathrm{a}}$ & .671 & .658 & .31964 \\
\hline \multicolumn{2}{|l|}{ a. Predictors: (Constant), impact, meaning, self, competency } \\
\hline
\end{tabular}

Table 6, the ANOVA table shows that the F value of (50.998) is significant at (0.05) level. Thus, hypothesis is rejected. So there is significant relationship between the employee empowerment and innovative work behavior. 
The Relationship between Employees' Empowerment and Innovative Work Behavior

Table6. ANOVA Table for Ho

\begin{tabular}{|l|l|l|l|l|l|l|}
\hline Model & Sum of Squares & df & Mean Square & F & Sig. \\
\hline \multirow{4}{*}{1} & Regression & 20.842 & 4 & 5.211 & 50.998 & $.000^{\mathrm{a}}$ \\
\cline { 2 - 7 } & Residual & 10.217 & 100 & .102 & & \\
\cline { 2 - 7 } & Total & 31.059 & 104 & & & \\
\hline
\end{tabular}

Table7. Coefficients table for Ho

\begin{tabular}{|c|c|c|c|c|c|c|}
\hline \multirow{2}{*}{\multicolumn{2}{|c|}{ Model }} & \multicolumn{2}{|c|}{ Unstandardized Coefficients } & \multirow{2}{*}{$\begin{array}{l}\text { Standardized Coefficients } \\
\text { Beta }\end{array}$} & \multirow[b]{2}{*}{$\mathrm{t}$} & \multirow[b]{2}{*}{ Sig. } \\
\hline & & $\mathrm{B}$ & Std. Error & & & \\
\hline \multirow[t]{5}{*}{1} & (Constant) & 1.587 & .393 & & 4.042 & .000 \\
\hline & meaning & -.064 & .049 & -.083 & -1.286 & .202 \\
\hline & competency & -.160 & .107 & -.116 & -1.496 & .138 \\
\hline & self & .167 & .071 & .180 & 2.361 & .020 \\
\hline & impact & .685 & .065 & .744 & 10.497 & .000 \\
\hline
\end{tabular}

Also according to the coefficient table it is found that $t$ _value for each independent variable is significant at 0.05 levels that means there is significant relationship of each variable with the dependent variable. As shown in details for each sub hypothesis in the following hypothesis.

H0a1-: There is no significant relationship between the (meaning) and innovative work behavior.

Multiple regressions is used to test this hypothesis, the results of regression the independent variables (meaning) against innovative work behavior can be seen in table 9 .

Table 9, shows that $\mathrm{R}$ (.165) is the correlation of the independent variables (Meaning) and innovative work behavior. Also it is found that R Square (.027), which is the explained variance.

Table9. Test of Hoal

\begin{tabular}{|l|l|l|l|l|}
\hline Model & $\mathrm{R}$ & $\mathrm{R}$ Square & Adjusted R Square & Std. Error of the Estimate \\
\hline 1 & $.165^{\mathrm{a}}$ & .027 & .018 & .54161 \\
\hline \multicolumn{4}{|l}{ a. Predictors: (Constant), meaning } \\
\hline
\end{tabular}

Table 10, the ANOVA table shows that the F value of (2.881) is significant at (0.05) level. Thus, hypothesis is rejected. So there is significant relationship between the independent variable (meaning) and innovative work behavior.

Table10. ANOVA Table for Hoal

\begin{tabular}{|l|l|l|l|l|l|l|}
\hline Model & Sum of Squares & Df & Mean Square & F & Sig. \\
\hline \multirow{3}{*}{1} & Regression & .845 & 1 & .845 & 2.881 & $.093^{\mathrm{a}}$ \\
\cline { 2 - 7 } & Residual & 30.214 & 103 & .293 & & \\
\cline { 2 - 7 } & Total & 31.059 & 104 & & & \\
\hline
\end{tabular}

Table11. Coefficients table for Hoal

\begin{tabular}{|c|c|c|c|c|c|c|}
\hline \multicolumn{2}{|c|}{ Model } & \multicolumn{2}{|c|}{ Unstandardized Coefficients } & Standardized Coefficients & \multicolumn{2}{l|}{ Sig. } \\
\cline { 3 - 7 } \multicolumn{2}{|c|}{} & B & Std. Error & Beta & t & .000 \\
\hline 1 & (Constant) & 4.908 & .330 & -.165 & -1.697 & .093 \\
\cline { 2 - 7 } & meaning & -.127 & .075 & & \multicolumn{5}{l}{} \\
\hline
\end{tabular}

Also according to the coefficient table it is found that $t$ _value for the independent variable (meaning) is significant at 0.05 levels that means there is significant relationship between meaning and innovative work behavior.

H0a2: There is no significant relationship between the (competency) and innovative work behavior.

Multiple regressions is used to test this hypothesis, the results of regression the independent variables (competency) against innovative work behavior can be seen in table 12 .

Table 12, shows that $\mathrm{R}\left(\mathbf{. 2 7 4} \mathbf{a}^{\mathrm{a}}\right.$ ) is the correlation of the independent variables (Meaning) and innovative work behavior. Also it is found that R Square (.075), which is the explained variance. 
Table12. Test of Hoa2

\begin{tabular}{|l|l|l|l|l|}
\hline Model & $\mathrm{R}$ & R Square & Adjusted R Square & Std. Error of the Estimate \\
\hline 1 & $.274^{\mathrm{a}}$ & .075 & .066 & .52806 \\
\hline
\end{tabular}

Table 13, the ANOVA table shows that the $\mathrm{F}$ value of $(\mathbf{8 . 3 8 6})$ is significant at $(0.05)$ level. Thus, hypothesis is rejected. So there is significant relationship between the employee empowerment (Competency) and innovative work behavior.

Table13. ANOVA table for Hoa2

\begin{tabular}{|l|l|l|l|l|l|l|}
\hline \multicolumn{2}{|l|}{ Model } & Sum of Squares & Df & Mean Square & F & Sig. \\
\hline \multirow{4}{*}{1} & Regression & 2.338 & 1 & 2.338 & 8.386 & $.005^{\mathrm{a}}$ \\
\cline { 2 - 7 } & Residual & 28.721 & 103 & .279 & & \\
\cline { 2 - 7 } & Total & 31.059 & 104 & & & \\
\hline
\end{tabular}

Table14. Coefficients Table for Hoa2

\begin{tabular}{|c|l|l|l|l|l|l|}
\hline \multicolumn{2}{|l|}{ Model } & Unstandardized Coefficients & Standardized Coefficients & \multicolumn{2}{l|}{} \\
\cline { 3 - 7 } \multicolumn{2}{|l|}{1} & B & Std. Error & Beta & t & Sig. \\
\cline { 2 - 7 } & comptant $)$ & 2.579 & .616 & & 4.187 & .000 \\
\hline \multicolumn{2}{|l|}{ a. Dependent Variable: dep } & .379 & .131 & .274 & 2.896 & .005 \\
\hline
\end{tabular}

Also according to the coefficient table it is found that $\mathrm{t}$-value for the independent variable (competency) is significant at 0.05 levels that means there is significant relationship between (competency) and innovative work behavior.

H0a3-: There is no significant relationship between the (self determination) and innovative work behavior.

Multiple regressions is used to test this hypothesis, the results of regression the independent variables (self determination) against innovative work behavior can be seen in table 15

Table 15 , shows that $\mathrm{R}\left(\mathbf{. 5 3 0}^{\mathbf{a}}\right)$ is the correlation of the independent variables (self determination) and innovative work behavior. Also it is found that R Square (.281), which is the explained variance.

Table15. Test of Hoa3

\begin{tabular}{|l|l|l|l|l|}
\hline Model & R & R Square & Adjusted R Square & Std. Error of the Estimate \\
\hline 1 & $.530^{\mathrm{a}}$ & .281 & .274 & .46577 \\
\hline \multicolumn{2}{|l|}{ a. Predictors: (Constant), self } \\
\hline
\end{tabular}

Table 16, the ANOVA table shows that the F value of (40.166) is significant at (0.05) level. Thus, hypothesis is rejected. So there is significant relationship between the employee empowerment (self determination) and innovative work behavior.

Table16. ANOVA table for Hoa3

\begin{tabular}{|l|l|l|l|l|l|l|}
\hline \multicolumn{2}{|l|}{ Model } & Sum of Squares & Df & Mean Square & F & Sig. \\
\hline \multirow{3}{*}{1} & Regression & 8.714 & 1 & 8.714 & 40.166 & $.000^{\mathrm{a}}$ \\
\cline { 2 - 7 } & Residual & 22.345 & 103 & .217 & & \\
\cline { 2 - 6 } & Total & 31.059 & 104 & & & \\
\hline
\end{tabular}

Table17. Coefficients table for Hoa3

\begin{tabular}{|l|l|l|l|l|l|l|}
\hline \multicolumn{2}{|l|}{ Model } & Unstandardized Coefficients & Standardized Coefficients & \multicolumn{2}{l|}{} \\
\cline { 3 - 7 } \multicolumn{2}{l|}{} & B & Std. Error & Beta & t & Sig. \\
\hline \multirow{2}{*}{1} & (Constant) & 2.193 & .344 & & 6.373 & .000 \\
\cline { 2 - 7 } & self & .491 & .078 & .530 & 6.338 & .000 \\
\hline \multicolumn{2}{|l|}{ a. Dependent Variable: dep }
\end{tabular}

Also according to the coefficient table it is found that $\mathrm{t}$ _value for the independent variable is significant at 0.05 level, that means there is significant relationship of employee empowerment (self determination) with the innovative work behavior. 
H0a4: There is no significant relationship between the (impact) and innovative work behavior.

Multiple regressions is used to test this hypothesis, the results of regression the independent variables (impact) against innovative work behavior can be seen in table 18

Table 18, shows that $\mathrm{R}\left(\mathbf{. 7 9 8}^{\mathrm{a}}\right)$ is the correlation of the independent variables (impact) and innovative work behavior. Also it is found that R Square (.636), which is the explained variance.

Table18. Test of Hoa4

\begin{tabular}{|l|l|l|l|l|}
\hline Model & $\mathrm{R}$ & R Square & Adjusted R Square & Std. Error of the Estimate \\
\hline 1 & $.798^{\mathrm{a}}$ & .636 & .633 & .33108 \\
\hline \multicolumn{4}{|l}{ a. Predictors: (Constant), impact } \\
\hline
\end{tabular}

Table 19, the ANOVA table shows that the F value of (180.353) is significant at $(0.05)$ level. Thus, hypothesis is rejected. So there is significant relationship between the employee empowerment (Impact) and innovative work behavior.

Table19. ANOVA table for Hoa4

\begin{tabular}{|l|l|l|l|l|l|l|}
\hline \multicolumn{2}{|l|}{ Model } & Sum of Squares & Df & Mean Square & F & Sig. \\
\hline \multirow{3}{*}{1} & Regression & 19.769 & 1 & 19.769 & 180.353 & $.000^{\mathrm{a}}$ \\
\cline { 2 - 7 } & Residual & 11.290 & 103 & .110 & & \\
\cline { 2 - 7 } & Total & 31.059 & 104 & & & \\
\hline
\end{tabular}

Table20. Coefficients table for Hoa4

\begin{tabular}{|l|l|l|l|l|l|l|}
\hline \multicolumn{2}{|l|}{ Model } & Unstandardized Coefficients & Standardized Coefficients & \multicolumn{3}{l|}{} \\
\cline { 3 - 8 } \multicolumn{2}{|l|}{} & B & Std. Error & Beta & t & Sig. \\
\hline 1 & (Constant) & 1.074 & .246 & & 4.359 & .000 \\
\cline { 2 - 8 } & impact & .735 & .055 & .798 & 13.430 & .000 \\
\hline \multicolumn{2}{|l|}{ a. Dependent Variable: dep }
\end{tabular}

Also according to the coefficient table it is found that $\mathrm{t}$ _value for the independent variable (Impact) is significant at 0.05 level, that means there is significant relationship of employee empowerment (Impact) with the innovative work behavior.

\section{H0b: There is no innovative work behavior at the companies in Jordan.}

H0b1: There is no significant relationship between the employee empowerment and (Originality).

Multiple regressions is used to test this hypothesis, the results of regression the independent variables (employee empowerment) against dependent variable (Originality) can be seen in table 21.

Table 21 , shows that $R\left(\mathbf{. 8 4 9}^{\mathrm{a}}\right)$ is the correlation of the independent variables and innovative work behavior. Also it is found that R Square (.721), which is the explained variance.

Table21. Test of Hobl

\begin{tabular}{|l|l|l|l|l|}
\hline Model & $\mathrm{R}$ & $\mathrm{R}$ Square & Adjusted R Square & Std. Error of the Estimate \\
\hline 1 & $.849^{\mathrm{a}}$ & .721 & .710 & .32272 \\
\hline \multicolumn{2}{|l|}{ a. Predictors: (Constant), impact, meaning, self, competency } \\
\hline
\end{tabular}

Table 22, the ANOVA table shows that the F value of (64.613) is significant at (0.05) level. Thus, hypothesis is rejected. So there is significant relationship between the employee empowerment and innovative work behavior (Originality).

Table22. ANOVA table for Hobl

\begin{tabular}{|c|c|c|c|c|c|c|}
\hline \multicolumn{2}{|c|}{ Model } & Sum of Squares & Df & Mean Square & $\mathrm{F}$ & Sig. \\
\hline \multirow[t]{3}{*}{1} & Regression & 26.918 & 4 & 6.730 & 64.613 & $.000^{\mathrm{a}}$ \\
\hline & Residual & 10.415 & 100 & .104 & & \\
\hline & Total & 37.333 & 104 & & & \\
\hline
\end{tabular}


Dr.Dina Alkhodary

Table23. Coefficients table for Hobl

\begin{tabular}{|l|l|l|l|l|l|l|}
\hline \multicolumn{2}{|l|}{ Model } & \multicolumn{2}{l|}{ Unstandardized Coefficients } & Standardized Coefficients & \multicolumn{2}{l|}{} \\
\cline { 3 - 7 } \multicolumn{2}{l|}{1} & B & Std. Error & Beta & t & Sig. \\
\hline & (Constant) & 1.835 & .396 & & 4.629 & .000 \\
\cline { 2 - 7 } & meaning & -.120 & .050 & -.142 & -2.400 & .018 \\
\cline { 2 - 7 } & competency & -.318 & .108 & -.210 & -2.935 & .004 \\
\cline { 2 - 7 } & self & .295 & .071 & .290 & 4.127 & .000 \\
\cline { 2 - 7 } & impact & .719 & .066 & .712 & 10.905 & .000 \\
\hline \multicolumn{2}{|l|}{ a. Dependent Variable: originalty }
\end{tabular}

Also according to the coefficient table it is found that $t$ _value for each dependent variable (innovative work behavior) is significant at 0.05 level, that means there is significant relationship of independent variable (employee empowerment) with the dependent variable (Originality).

H0b2: There is no significant relationship between the employee empowerment and (Fluency of ideas).

Multiple regressions is used to test this hypothesis, the results of regression the independent variables against innovative work behavior (Fluency of ideas) can be seen in table 24

Table 24, shows that $\mathrm{R}\left(.784^{\mathrm{a}}\right.$ ) is the correlation of the independent variables (employee empowerment) and innovative work behavior (Fluency of ideas). Also it is found that R Square (.615), which is the explained variance.

Table24. Test of $\mathrm{Ho}$

\begin{tabular}{|l|l|l|l|l|}
\hline Model & R & R Square & Adjusted R Square & Std. Error of the Estimate \\
\hline 1 & $.784^{\mathrm{a}}$ & .615 & .600 & .36463 \\
\hline \multicolumn{4}{|l}{ a. Predictors: (Constant), impact, meaning, self, competency } \\
\hline
\end{tabular}

Table 25, the ANOVA table shows that the F value of (39.933) is significant at (0.05) level. Thus, hypothesis is rejected. So there is significant relationship between the employee empowerment and innovative work behavior (Fluency of ideas).

Table25. ANOVA table for Hob2

\begin{tabular}{|l|l|l|l|l|l|l|}
\hline Model & Sum of Squares & Df & Mean Square & F & Sig. \\
\hline \multirow{4}{*}{1} & Regression & 21.238 & 4 & 5.309 & 39.933 & $.000^{\mathrm{a}}$ \\
\cline { 2 - 7 } & Residual & 13.296 & 100 & .133 & & \\
\cline { 2 - 6 } & Total & 34.533 & 104 & & & \\
\hline
\end{tabular}

Table26. Coefficients table for Hob2

\begin{tabular}{|l|l|l|l|l|l|l|}
\hline \multicolumn{2}{|l|}{ Model } & \multicolumn{2}{l|}{ Unstandardized Coefficients } & Standardized Coefficients & \multicolumn{2}{l|}{} \\
\cline { 3 - 7 } \multicolumn{2}{|l}{1} & B & Std. Error & Beta & t & Sig. \\
\hline \multirow{1}{*}{1} & (Constant) & 1.348 & .448 & & 3.009 & .003 \\
\cline { 2 - 7 } & meaning & .130 & .056 & .160 & 2.299 & .024 \\
\cline { 2 - 7 } & competency & -.289 & .122 & -.198 & -2.362 & .020 \\
\cline { 2 - 7 } & self & -.017 & .081 & -.018 & -.213 & .832 \\
\cline { 2 - 7 } & impact & .840 & .074 & .865 & 11.273 & .000 \\
\hline \multicolumn{2}{|l|}{ a. Dependent Variable: fluency }
\end{tabular}

Also according to the coefficient table it is found that $t$ _value for each independent variable is significant at 0.05 level, that means there is significant relationship of each variable with the dependent variable (Fluency of ideas).

H0b3: There is no significant relationship between the employee empowerment and (Problem sensitivity).

Multiple regressions is used to test this hypothesis, the results of regression the independent variables (employee empowerment) and innovative work behavior (Problem sensitivity) can be seen in table 27.

Table 27, shows that $\mathrm{R}\left(.686^{\mathrm{a}}\right.$ ) is the correlation of the independent variables (employee empowerment) and innovative work behavior (Problem sensitivity). Also it is found that R Square (.470), which is the explained variance. 
Table27. Test of Hob3

\begin{tabular}{|l|l|l|l|l|}
\hline Model & $\mathrm{R}$ & R Square & Adjusted R Square & Std. Error of the Estimate \\
\hline 1 & $.686^{\mathrm{a}}$ & .470 & .449 & .47162 \\
\hline
\end{tabular}

Table 28, the ANOVA table shows that the F value of (22.207) is significant at $(0.05)$ level. Thus, hypothesis is rejected. So there is significant relationship between the employee empowerment and innovative work behavior (Problem sensitivity).

Table28. ANOVA table for Hob3

\begin{tabular}{|l|l|l|l|l|l|l|}
\hline Model & Sum of Squares & Df & Mean Square & F & Sig. \\
\hline \multirow{4}{*}{1} & Regression & 19.757 & 4 & 4.939 & 22.207 & $.000^{\mathrm{a}}$ \\
\cline { 2 - 7 } & Residual & 22.243 & 100 & .222 & & \\
\cline { 2 - 7 } & Total & 42.000 & 104 & & & \\
\hline
\end{tabular}

Table29. Coefficients table for Hob3

\begin{tabular}{|l|l|l|l|l|l|l|}
\hline \multicolumn{2}{|l|}{ Model } & \multicolumn{2}{l|}{ Unstandardized Coefficients } & Standardized Coefficients & \multicolumn{2}{l|}{} \\
\cline { 3 - 7 } \multicolumn{2}{l|}{} & B & Std. Error & Beta & t & Sig. \\
\hline \multirow{1}{*}{1} & (Constant) & 1.578 & .579 & & 2.724 & .008 \\
\cline { 2 - 7 } & meaning & -.201 & .073 & -.224 & -2.749 & .007 \\
\cline { 2 - 7 } & competency & .125 & .158 & .078 & .793 & .430 \\
\cline { 2 - 7 } & self & .224 & .104 & .207 & 2.141 & .035 \\
\cline { 2 - 7 } & impact & .498 & .096 & .465 & 5.166 & .000 \\
\hline \multicolumn{2}{|l|}{ a. Dependent Variable: sensitivity }
\end{tabular}

Also according to the coefficient table it is found that $\mathrm{t}$ _value for the dependent variable is significant at 0.05 levels that mean there is significant relationship of each variable (employee empowerment ) with the dependent variable (problem sensitivity).

\section{RESUlTS OF THE STUDY}

The statistical analysis shows the following results:

The frequencies were as follow:

\section{The Descriptive Analysis was as Follow}

- Most of the respondents agrees that they think that their responsibilities are meaningful were the standards deviations of their answers were .621 .

- Most of the respondents agree that they think that they have the competency to handle their jobs were the standards deviations of their answers were .342 .

- Most of the respondents agree that they think they can define alternatives were the standards deviations of their answers were .599 .

- Most of the respondents agree that they think they have the ability to make a difference in their department were the standards deviations of their answers were .721 .

- Most of the respondents agree that they think they creates unique thoughts at their work were the standards deviations of their answers were .614.

- Most of the respondents agree that they think they create new ideas frequently were the standards deviations of their answers were .621 .

- Most of the respondents agree that they think they were aware about the needs for new approaches at work were the standards deviations of their answers were .721 .

\section{Hypothesis TeST}

1. The statistical analysis shows that the first hypothesis is rejected There is no significant relationship between the employee empowerment and innovative work behavior, since the regression analysis shows $\mathbf{R}$ Square $=.671$ and $\mathrm{F}$ test $=50.998$ at significant level $=0 \%$ which is $<.05$ then we reject $\mathrm{H} 01$ 
H0a1: is rejected (There is no significant relationship between the (meaning) and innovative work behavior.)

H0a2: is rejected since (There is no significant relationship between the (competency) and innovative work behavior.)

H0a3: is rejected

(There is no significant relationship between the (self determination) and innovative work behavior.)

H0a4: is rejected

(There is no significant relationship between the (impact) and innovative work behavior.)

- The study shows that there is a positive relationship between meaning, competency, self determination, Impact and innovative work behavior.

\section{H0b: is Rejected}

\section{There is no Innovative Work Behavior at the Companies In Jordan.}

H0b1: is rejected

There is no significant relationship between the employee empowerment and (Originality).

H0b2: is rejected

There is no significant relationship between the employee empowerment and (Fluency of ideas).

H0b3: is rejected

There is no significant relationship between the employee empowerment and (Problem sensitivity).

\section{CONCLUSION AND CONTRIBUTION OF THE STUDY}

The study provides many contributions to the future research. First, the study provided an indicator of the importance of the employees empowerment, Second the study focus on the employees empowerment (Meaning, Competency, self determination, Impact) and innovative work behavior (Originality, Fluency of ideas, Problem sensitivity), which is the most important behavior that has an influence over the employees for achieving high performance. Third the study showed to which extent Jordan as a developing country is applying the employees empowerment depending on some cultural aspects.

\section{SUMMARY OF THE STUDY}

In this paper, I have attempted to suggest a new emphasis on the employee empowerment (Meaning, Competency, self determination, Impact) and innovative work behavior (Originality, Fluency of ideas, Problem sensitivity). I suggest that to make progress we do need fully acceptance from the managers of the importance of the employee empowerment in order to get outstanding results on their effort, behavior as well as their performance.

\section{RECOMMENDATION}

- The companies should get attention to the importance of employee empowerment (Meaning, Competency, self determination, Impact).

- The companies should get attention to the importance of the innovative work behavior (Originality, Fluency of ideas, Problem sensitivity)on general and work environment in specific.

- The future researches could study the employee empowerment from other perspectives and with other variables

- The future researches could study the advertisement agencies as a sample of the study.

- The future researches could study the same variable on other sectors, and other countries to find the differences between countries.

\section{ACKNOWLEDGEMENTS}

Part of this research was supported by the researches and the related articles, The author would like to thank all the participant for their helpful of this manuscript. 


\section{REFERENCES}

[1] Aamir .Saeed, Abdul-Qayyum. Chaudhry, Shahbaz. Ahmad, Ghalib. Ata1 (2013) "Measuring the impact of empowerment on job satisfaction among the Middle Level managers of JVC Descon Lahore", Public Policy and Administration Research www.iiste.org ISSN 22245731(Paper) ISSN 2225-0972(Online) Vol.3, No.4.

[2] Baek-Kyoo.Joo, Ji, Hyun Shim (2010) "Psychological empowerment and organizational commitment: the moderating effect of organizational learning culture" Human Resource Development International, Volume 13, Issue 4 pages 425-441.

[3] Bowen, David E. \& Lawler III, Edward E. 1992. The empowerment of service workers: What, why, how and when, Sloan Management Review, 33(3): 31-39.

[4] Carmeli, A., Meitar, R., \& Weisberg, J. (2006). Self-leadership skills and innovative behavior at work. International Journal of Manpower, 27(1), 75-90.

[5] Conger, J. A. and Kanungo, R. N. 1988. The empowerment process: Integration theory and practice, Academy of Management Journal, 13 (3): 471-482.

[6] De Jong, J., \& Den Hartog, D. (2007). How leaders influence employees' innovative behaviour. European Journal of Innovation Management, 10(1), 41-64.

[7] De Jong, J., \& Den Hartog, D. (2010). Measuring Innovative Work Behaviour. Creativity and Innovation Management, 19(1), 23-36.

[8] George .Van Leeuwen, Luuk . Klomp(2006)"On the contribution of innovation to multi-factor productivity growth" Economics of Innovation and New Technology, Volume 15, Issue 4-5.

[9] Hans.Loof ,Almas,Heshmati (2006) "On the relationship between innovation and performance: A sensitivity analysis" Economics of Innovation and New Technology, Volume 15, Issue 4-5.

[10] Hasan. Tutar, Mehmet. Altinoz2, Demet. Cakiroglu (2011) "The effects of employee empowerment on achievement motivation and the contextual performance of employees" African Journal of Business Management Vol. 5(15).

[11] Hill, F (Hill, F); Huq, R (Huq, R) (2004) "Employee empowerment: Conceptualizations, aims and outcomes" TOTAL QUALITY MANAGEMENT \& BUSINESS EXCELLENCE, Volume: 15 , Issue: 8 .

[12] James F. Fairbank, Scott David Williams (2001) "Motivating Creativity and Enhancing Innovation through Employee Suggestion System Technology", Creativity and Innovation Management, Volume 10, Issue 2, pages 68-74.

[13] Janssen, O. (2000). Job demands, perceptions of effort-reward fairness and innovative work behaviour. Journal of Occupational and Organizational Psychology, 73, 287-302.

[14] Janssen, O. (2003). Innovative behaviour and job involvement at the price of conflict and less satisfactory relations with co-workers. Journal of Occupational and Organizational Psychology, 76, 347-364.

[15] Janssen, O., Van de Vliert, E., \& West, M. (2004). The bright and dark sides of individual and group innovation: a Special Issue introduction. Journal of Organizational Behavior, 25, 129145.

[16] Janssen,O. (2004) "The barrier effect of conflict with superiors in the relationship between employee empowerment and organizational commitment", work \& Stress: An International Journal of Work, Health \& Organisations, Volume .18, Issue:1.

[17] Jyotsna Bhatnagar (2007) "Predictors of organizational commitment in India: strategic HR roles, organizational learning capability and psychological empowerment" The International Journal of Human Resource Management, Volume 18, Issue 10.

[18] Kanter, R. M. (1988). When a Thousand Flowers Bloom: Structural, Collective, and Social Conditions for Innovation in Organisations.". In B. M. Staw \& L. L. Cummings (Red.), Research in Organizational Behavior (Vol. 10, pp. 93-131). Greenwich: J.A.I. Press.

[19] Kleysen, R. F., \& Street, C. T. (2001). Toward a multi-dimensional measure of individual innovative behavior. Journal of Intellectual Capital, 2(3), 284-296.

[20] Luuk. Klomp , George .Van Leeuwen (2001)"Linking Innovation and Firm Performance: A New Approach" International Journal of the Economics of Business, Volume 8, Issue 3. 
[21] Melinda J. Moye, Alan B. Henkin, (2006) "Exploring associations between employee empowerment and interpersonal trust in managers", Journal of Management Development, Vol. 25 Iss: 2, pp. $101-117$.

[22] Onne Janssen (2005) "The joint impact of perceived influence and supervisor supportiveness on employee innovative behavior" Journal of Occupational and Organizational Psychology, Volume 78, Issue 4, pages 573-579.

[23] ONNE JANSSEN, EVERT VAN DE VLIERT, MICHAEL WEST (2004) "The bright and dark sides of individual and group innovation: a Special Issue introduction" Journal of Organizational Behavior J. Organiz. Behav. 25, 129-145.

[24] Scott, S. G., \& Bruce, R. A. (1994). Determinants of innovative behavior: A path model of individual innovation in the workplace. Academy of Management Journal, 37(3), 580-607.

[25] Thomas, K. W. \& Velthouse, B. A. 1990. Cognitive elements of empowerment: An interpretive model of intrinsic motivation. Academy of Management review, 15(4): 666- 681.

[26] Tuominen, T., \& Toivonen, M. (2011). Studying innovation and change activities in KIBS through the lens of innovative behaviour. International Journal of Innovation Management, 15(02), 393-422. doi:10.1142/S1363919611003209.

[27] Yuan, F., \& Woodman, R. (2010). Innovative Behavior in the workplace: The role of performance and image outcome expectations. Academy of Management Journal, 53(2), 323342.

[28] Zemke, R \& Schaaf, D. 1989. The service edge: 101 companies that profit from customer care. New York, N. Y. American Library.

\section{SURVEY OF THE STUDY}

Dear Mrs./MR

Thank you for giving us the opportunity to enhance the scientific research in Jordan.

Our research title is "The relationship between employee empowerment and innovative work behavior"

Please help us by taking a few minutes to tell us about the information which you share with your employees. We appreciate your business and want to help in developing the business in Jordan.

The information will just be used for academic research purpose.

Sincerely

Dr.Dina Alkhodary

Assistant Professor

Al-Israa Privet University

\section{PART 1:}

\section{Position}

Officer

Senior

Manager

\section{Gender}

Male

Female

\section{Level of Experience}

Less than 3 years

3-5 years

More than 5 years 


\section{Level of Education}

Diploma degree

Bachelor degree

Master degree

\section{PART 2:}

\begin{tabular}{|c|c|c|c|c|c|c|}
\hline & & \begin{tabular}{|l|}
$\begin{array}{l}\text { Strongly } \\
\text { agree }\end{array}$ \\
\end{tabular} & agree & Neutral & Disagree & $\begin{array}{l}\text { Strongly } \\
\text { Disagree }\end{array}$ \\
\hline & Employee empowerment & & & & & \\
\hline 1 & I think that my job`s objectives are meaningful & & & & & \\
\hline 2 & I think that my responsibilities are meaningful & & & & & \\
\hline 3 & I think that my organizational purpose is meaningful & & & & & \\
\hline 4 & I am satisfied with my current job because it is meaningful & & & & & \\
\hline 5 & I think the I have a required skills to handle my job & & & & & \\
\hline 6 & I think that I have the competency to handle my job & & & & & \\
\hline 7 & I think I have enough experience to handle my job & & & & & \\
\hline 8 & I think that I am self determine & & & & & \\
\hline 9 & I think I can define alternatives & & & & & \\
\hline 10 & I think I can choose between the alternative & & & & & \\
\hline 11 & $\begin{array}{l}\text { I think I have the ability to make a difference in my work } \\
\text { environment. }\end{array}$ & & & & & \\
\hline \multirow[t]{2}{*}{12} & $\begin{array}{l}\text { I think I have the ability to make a difference in my } \\
\text { department. }\end{array}$ & & & & & \\
\hline & Work innovative behavior & & & & & \\
\hline 13 & I think I creates unique thoughts at my work & & & & & \\
\hline 14 & $\begin{array}{l}\text { I think I creates unusual ideas, or the first of a kind idea at } \\
\text { my work }\end{array}$ & & & & & \\
\hline 15 & I think that I create new ideas frequently & & & & & \\
\hline 16 & I think I am deterring problems clearly & & & & & \\
\hline 17 & I think that I am aware about the needs for change & & & & & \\
\hline 18 & $\begin{array}{l}\text { I think that I am aware about the needs for new approaches } \\
\text { at work }\end{array}$ & & & & & \\
\hline
\end{tabular}

\section{AUTHOR's BIOGRAPHY}

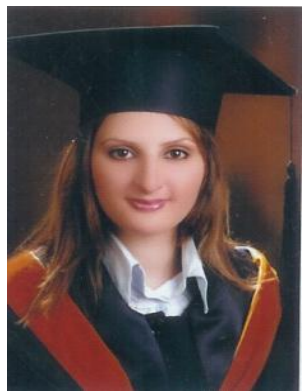

Dr. Dina Alkhodary, she received her $\mathrm{PhD}$ Degree from Amman Arab University, Jordan, in 2012, MBA degree from New York Institute of Technology, in 2006 and completed her Bs. degree from Al Yarmouk University, in 2004.she is Assistant Professor at Al Isra Privet University with department of Business before that she was assistant professor at kingdom university and part time instructor at German university. Beside her job as academic instructor she is certified trainer and academic researcher and she hold the position of master thesis external examiner at NYIT. 